\title{
The Role of Immune Cells in Chronic HBV Infection
}

\author{
Hai-Jun Li, Nai-Cui Zhai, Hong-Xiao Song, Yang Yang, An Cui, Tian-Yang Li and Zheng-Kun Tu* \\ Department of Translational Medicine, The First Hospital, Jilin University, Changchun, Jilin, China
}

\begin{abstract}
Hepatitis B virus (HBV) infection is a major cause of chronic liver diseases that may progress to liver cirrhosis and hepatocellular carcinoma. Host immune responses are important factors that determine whether HBV infection is cleared or persists. After infection, viral replication occurs inside hepatocytes, and the secretion of infectious virions can take place at high rates for decades. Consequently, HBV DNA and viral proteins, like HBV early antigen ( $\mathrm{HBeAg}$ ) and HBV surface antigen ( $\mathrm{HBsAg})$, can be easily detected in serum. Chronic infection with HBV is the result of an ineffective antiviral immune response towards the virus. In this review, we discuss the role of immune cells in chronic HBV infection. (C) 2015 The Second Affiliated Hospital of Chongqing Medical University. Published by XIA \& HE Publishing Ltd. All rights reserved.
\end{abstract}

\section{Introduction}

Hepatitis B virus (HBV) infection is a major health problem, affecting around 350 million people worldwide, despite the availability of a prophylactic vaccine. ${ }^{1}$ Although the majority of infected individuals clear the virus spontaneously, a fraction of patients is unable to clear the virus and develops a chronic form of hepatitis. The number of chronically infected patients has already reached over 240 million. ${ }^{2}$ In time, these patients are at high risk of developing HBV-related diseases, such as liver cirrhosis and hepatocellular carcinoma (HCC), which account for 600,000 deaths annually. ${ }^{3}$

Chronicity of HBV is the result of a complex interaction between the replicating virus and an inadequate immune response. $^{4-6}$ After infection, viral replication takes place inside hepatocytes, and the secretion of infectious virions can occur at high rates for decades. Consequently, HBV DNA and viral proteins, like HBV early antigen (HBeAg) and HBV

Keywords: Immune cells; Natural killer cells; $\mathrm{CD}^{+}{ }^{+}$T cells; Hepatitis B virus. Abbreviations: $A D C C$, antibody-dependent cytotoxicity; APCs, antigen presenting cells; CHB, chronic hepatitis B; CTLA-4, cytotoxic T lymphocyte antigen 4; DC, dendritic cells; HBeAg, HBV early antigen; HBsAg, HBV surface antigen; HBV, hepatitis B virus; HCC, hepatocellular carcinoma; IFN- $\gamma$, interferon gamma; IL, interleukin; IPC, interferon producing cell; KCs, Kupffer cells; LPS, lipopolysaccharide; mDC, myeloid DC; MHC I, major histocompatibility complex $1 ; \mathrm{MOH}_{\text {, }}$ Ministry of Health of China; NK, natural killer; NKG2A, NK group 2A; PBMC, peripheral blood mononuclear cell; PD-1, programmed death-1; pDC1, precursor DC1; PD-L, PD ligand; TGF- $\beta$, transforming growth factor beta; Tim-3, T cell immunoglobulin- and mucin-domain-containing molecule-3; TLR2, toll-like receptor 2; Tregs, regulatory T cells.

Received: 30 July 2015; Revised: 20 October 2015; Accepted: 28 October 2015 DOI: $10.14218 / \mathrm{JCTH} .2015 .00026$.

*Correspondence to: Zheng-Kun Tu, The First Hospital, Jilin University, Changchun 130061, Jilin, China. Tel: +86-0431-88783044, Fax: +86-0431-88783044, E-mail: tuzhengkun@hotmail.com surface antigen (HBsAg), can be easily detected in serum. The levels of these clinical markers may fluctuate over time and are a reflection of disease activity and commonly used to define disease stage. ${ }^{5,6}$

The liver is an immune organ that contains diverse immunologically active cell types, including both lymphocytes and myeloid cells. ${ }^{7}$ It has been puzzling for years why some patients develop chronic hepatitis while HBV infection resolves without clinical consequences in others, and why viral infection is not cleared in chronic carriers. Although these issues are unresolved, it has been speculated that aberrant immune tolerance in chronic hepatitis and HBV carriers plays an important role in impairing the immune responses for viral clearance. ${ }^{8,9}$ Chronic infection with $\mathrm{HBV}$ is the result of an ineffective antiviral immune response towards the virus. ${ }^{10-12}$ The exact mechanism by which HBV escapes immunity is still not known. The role of immune cells in chronic HBV infection will be discussed in this review.

\section{HBV epidemiology in China}

Infection with HBV and development of HCC are responsible for heavy disease burdens in China. In 2006, the Ministry of Health of China ( $\mathrm{MOH}$ ) estimated that, among Chinese aged 1 to 59 years as of 1992 , the national prevalence of HBV infection and HBV carriers was $57.63 \%$ and $9.75 \%$, respectively, which corresponded to 690 million infected people, 120 million carriers, and 20 million with chronic hepatitis (Table 1). ${ }^{13}$ The disease burden of HBV is very large, even when compared to that of tuberculosis, which was only responsible for 1.4 million new cases in $2000 .^{14}$ Chronic hepatitis $B$ $(\mathrm{CHB})$ is one of the most serious infectious diseases in China.

To date, the $\mathrm{MOH}$ has taken several measures to address HBV. In its National Plan for Prevention and Treatment against Hepatitis B for 2006-2010, the MOH stated that CHB causes serious consequences for patients, their families, and society as a whole and that it is a major cause of poverty and a health issue of the highest priority. The prevalence of HBV infection in China is one of the highest in the world. In addition, China has the highest incidence of HCC (37.9 and 14.2 for males and females, respectively, per 100,000 world standard 340,000 cases), with 630,000 newly diagnosed cases in 2002. ${ }^{15}$

In China, HBV is the most important risk factor for the development of HCC. Although the HBV immunization program is expected to greatly reduce HCC incidence, a few more decades are required before an obvious decrease among the general population will be seen. With the high cost of the current antiviral therapy for CHB, HCC control among existing carriers depends on reducing risk factors that accelerate the development of HCC among carriers. Since the introduction of HBV immunization, control of HBV infection 
Table 1. Epidemiology survey of hepatitis B virus infection in 1992

\begin{tabular}{|c|c|c|}
\hline Region & Province & $\begin{array}{l}\text { HBsAg } \\
(\%)\end{array}$ \\
\hline NorthEast & Heilongjiang, Jilin, Liaoning & 10.71 \\
\hline NorthCentral & $\begin{array}{l}\text { Neimenggu, Beijing, Tianjin, } \\
\text { Hebei, Shanxi }\end{array}$ & 5.53 \\
\hline East & $\begin{array}{l}\text { Shandong, Jiangsu, Shanghai, } \\
\text { Zhejiang, Anhui, Jiangxi, Fujian }\end{array}$ & 9.94 \\
\hline SouthCentral & $\begin{array}{l}\text { Henan, Hubei, Hunan, } \\
\text { Guangdong, Guangxi }\end{array}$ & 12.75 \\
\hline SouthWest & $\begin{array}{l}\text { Xizang, Sichuan, Yunnan, } \\
\text { Guizhou }\end{array}$ & 8.90 \\
\hline NorthWest & $\begin{array}{l}\text { Xinjiang, Gansu, Qinghai, } \\
\text { Ningxia, Shangxi }\end{array}$ & 8.68 \\
\hline
\end{tabular}

HBsAg, hepatitis B surface antigen.

has been substantially progressing in China, which will lead to a dramatic decrease in the disease burden from HBV infection and HCC. ${ }^{16}$ Therefore, understanding the role of immune cells in chronic HBV infection will become more and more important.

\section{$\mathrm{CDB}^{+} \mathrm{T}$ cells}

$\mathrm{CD}^{+} \mathrm{T}$ cells are a major component of cellular adaptive immunity, and they normally mediate protection against intracellular pathogens and tumor cells. In order to be properly activated, $\mathrm{CD} 8^{+} \mathrm{T}$ cells require at least two signals: first, the recognition of their cognate antigen presented by major histocompatibility complex 1 (MHC I) molecules on antigen presenting cells (APCs). This is mediated by the interaction between the antigen-specific $T$ cell receptor and the peptideMHC I complex. Second, additional costimulatory signals have to be provided by the same APC to prevent anergy. Different cytokine milieus may influence this activation process. ${ }^{17-19}$

In chronically HBV-infected individuals, virus-specific $\mathrm{CD}^{+} \mathrm{T}$ cell responses are rarely detectable. ${ }^{20-24}$ The profiles of HBV specific CD8 ${ }^{+} \mathrm{T}$ cell responses depend on the stage of disease and are highly influenced by the level of HBV replication. Indeed, circulating multispecific $\mathrm{HBV}$-specific $\mathrm{CD}^{+} \mathrm{T}$ cell responses are predominantly detectable ex vivo in patients with low viral load. Furthermore, HBV-specific $\mathrm{CD} 8^{+} \mathrm{T}$ cells may not or only insufficiently be primed by APCs and, consequently, may not expand upon antigen-encounter. Accordingly, $\mathrm{HBV}$-specific $\mathrm{CD}^{+} \mathrm{T}$ cells would be expected to display a naïve phenotype, characterized by high expression levels of CD45RA, CD27, CD28, and CCR7. ${ }^{25}$

$\mathrm{CD}^{+} \mathrm{T}$ cell dysfunction in chronic HBV infection follows a well-established pattern with elevated expression of inhibitory molecules, such as programmed death-1 (PD-1), ${ }^{26,27}$ cytotoxic T lymphocyte antigen 4 (CTLA-4), ${ }^{28}$ Tim-3, ${ }^{29,30}$ and 2B4 (CD244). ${ }^{31}$ Furthermore, the expression of corresponding ligands, such as PD ligand (PD-L) 1 , has been shown to be increased on hepatocytes. ${ }^{32}$ Therefore, highly viremic HBV-infected patients exhibit a more severely impaired $\mathrm{CD}^{+} \mathrm{T}$ cell phenotype and more profound $\mathrm{T}$ cell dysfunction in the liver than in the blood. ${ }^{27,33}$ Blockade of these inhibitory pathways may at least partially restore
HBV-specific $\mathrm{CD}^{+} \mathrm{T}$ cell functionality, as demonstrated in vitro. ${ }^{31}$ The potential relevance of blocking the PD-1 pathway was shown in the HBV mouse model, where HBVtransgenic mice were treated with blocking antibodies for PD-L1 prior to the adoptive transfer of HBV-specific cytotoxic T cells. ${ }^{34}$ Moreover, the lack of CD4 ${ }^{+} \mathrm{T}$ cell help was shown to contribute to defective CD8 ${ }^{+}$T cell function. ${ }^{35}$ The increase in regulatory $T$ cell (Treg) numbers ${ }^{36-38}$ and immunosuppressive cytokines, such as interleukin (IL)-10 and transforming growth factor beta (TGF- $\beta$ ), ${ }^{39}$ impaired virus-specific $C D 8^{+}$ $T$ cell responses. It has also been reported that increased intrahepatic arginase levels ${ }^{40}$ and, hence, the lack of arginine, led to a functional silencing of $\mathrm{CD}^{+} \mathrm{T}$ cells due to the downregulation of the $\mathrm{CD} 3 \zeta$-chain. ${ }^{41}$

T-cell exhaustion is regulated by a complex network of coexpressed inhibitory receptors that act synergistically and redundantly. Hence, a better understanding of the diverse inhibitory receptors involved in the regulation of exhausted Tcells will pave the way for the development of more effective immunotherapeutic and prophylactic strategies for the treatment of chronic infectious diseases. ${ }^{42}$ Recently, several studies have provided insight into the transcriptional mechanisms behind T-cell exhaustion in chronic infection. The transcription factor T-bet was shown to repress directly the expression of inhibitory receptor PD-1 and to sustain virusspecific $\mathrm{CD}^{+}{ }^{+} \mathrm{T}$-cell responses during chronic infection, as its expression was downregulated in exhausted $\mathrm{CD}^{+} \mathrm{T}$ cells in response to persisting antigen. ${ }^{43}$ In addition, a critical role of T-bet for viral clearance was demonstrated for HBV infection, where T-bet deficiency was more characteristic of a chronic evolving infection. ${ }^{44}$

\section{Regulatory T cells}

Recent advances in the understanding of the properties of $\mathrm{CD} 4{ }^{+} \mathrm{CD} 25^{+}$Tregs have provided new insights into the mechanism by which immune tolerance is maintained or broken in various disease conditions. ${ }^{45-47}$ Significant deficits in the number and function of these Tregs were found in autoimmune diseases and persistent infections. ${ }^{48-51}$ These studies have demonstrated the importance of $C D 4{ }^{+} \mathrm{CD} 25^{+}$Tregs in various immune-related diseases and have provided a clue for exploring the role of $C D 4^{+} C D 25^{+}$Tregs in hepatitis $B .{ }^{52,53}$

It has been reported that immune tolerance in chronic hepatitis may be associated with $\mathrm{CD} 4^{+} \mathrm{CD} 25^{+}$Tregs. The increased frequency of $\mathrm{CD} 4^{+} \mathrm{CD} 25^{+}$Foxp $3^{+} \mathrm{T}$ cells was associated with serum levels of TGF- $\beta$, which is known to promote peripheral conversion of $\mathrm{CD} 4^{+} \mathrm{CD} 25^{-} \mathrm{T}$ cells to $\mathrm{CD}^{+}{ }^{+} \mathrm{CD} 25^{+} \mathrm{Foxp}^{+}$Tregs. The gene products of $\mathrm{HBV}$, such as the envelope proteins, may directly induce $\mathrm{CD} 4^{+} \mathrm{CD} 25^{+} \mathrm{Foxp}^{+}$Tregs through antigen recognition. Similar situations with $T$ cell receptor peptides or toll-like receptor 2 (TLR2) in the induction of $C D 4^{+} \mathrm{CD} 25^{+}$Tregs have been reported. ${ }^{54}$ TGF- $\beta$ serum levels correlated significantly with the expression of Foxp3 and the frequency and function of $\mathrm{CD} 4{ }^{+} \mathrm{CD} 25^{+}$Tregs in chronic hepatitis patients. On the other hand, $\mathrm{CD} 4^{+} \mathrm{CD} 25^{+}$Tregs could secret IL-10 to inhibit $\mathrm{NK}$ cell and $\mathrm{CD}^{+}$T cell antivirus response. ${ }^{55}$

The HBV-specific immune response could be suppressed by $\mathrm{CD} 4^{+} \mathrm{CD} 25^{+}$Tregs in patients with HBV infection. Tregs not only from $\mathrm{CHB}$ patients but also those from patients with resolved HBV infection suppressed HBV specific $\mathrm{CD} 8^{+}$ $T$ cells. However, it has been reported that the frequency of Tregs in CHB patients was significantly higher than that in 
healthy controls and those with resolved HBV infection. ${ }^{56}$ Therefore, the frequency of Tregs might contribute to the disease status of HBV infection. Another group reported that the frequency of $\mathrm{CD} 39^{+}$Tregs correlated with the progression of HBV infection. Therefore, we should consider this minor subset of Tregs in CHB patients. Previously, we reported that $\mathrm{HBCAg}$-specific IL-10 secreting $\mathrm{CD} 4^{+} \mathrm{CD} 25^{+}$Tregs might contribute to the suppression of $\mathrm{HBV}$-specific interferon gamma (IFN- $\gamma$ ) secreting CD4 ${ }^{+}$T cells. ${ }^{57}$ Tregs might contribute to the suppression of HBV-specific T cells. Therefore, treatment with a nucleos(t)ide analogue might affect the Tregs.

\section{NK cells}

NK cells represent the main effector cell population involved in innate immune responses against intracellular pathogens and abnormal cells. ${ }^{58}$ They are enriched in the liver and account for one-third of the intrahepatic lymphocytes, compared to $5-15 \%$ in the peripheral blood. ${ }^{59,60}$ Studies regarding phenotype and function of NK cells during chronic HBV infection have revealed, in part, conflicting results. Several reports have concluded that NK cells exhibit selective defects in their antiviral function. This functional dichotomy features conserved or enhanced cytolytic activity and diminished cytokine production that may contribute to viral persistence and implicate a role for NK cells in disease pathogenesis. ${ }^{61-63}$ The mechanisms leading to this functional impairment are still not fully understood but are thought to be heterogeneous.

HBV infection may alter the activation status and receptor expression patterns on the surface of NK cells. Indeed, the expression of inhibitory receptors, such as NK group 2A (NKG2A), was shown to be elevated, while the activating receptors CD16 and NKp30 were downregulated. ${ }^{63,64}$ These changes were correlated with serum HBV DNA load. In addition to classical NK cell receptors, other co-inhibitory molecules involved in immune responses may impair NK cell function. Notably, Tcell immunoglobulin- and mucin-domain-containing molecule-3 (Tim-3) has been shown to be upregulated on NK cells during HBV infection, and in vitro blockade of Tim-3 was able to enhance NK cell cytotoxicity. ${ }^{65}$

Impaired NK cell activation and function may also arise from modified expression patterns of ligands for inhibitory and activating NK cell receptors. ${ }^{66}$ Furthermore, the immunosuppressive cytokine environment in chronic HBV infection, created through high levels of IL-10, may inhibit the ability of NK cells to produce IFN- $\gamma_{1}{ }^{67}$ as was previously shown in acutely infected patients. This defect persisted in patients with chronic HBV infection receiving antiviral therapy but was reversed in vitro by specific blockade of IL-10 and TGF- $\beta .{ }^{67}$

Chronic HBV infection is the key driving force for the development of hepatic cirrhosis and HCC. In developing countries, the risk for developing HBV-related HCC is $70 \%$. The frequency, activation, and cytokine production of circulating NK cells were significantly reduced in CHB patients compared with healthy controls. Increased secretion of the immunosuppressive cytokine IL-10 in CHB patients suppressed NK cell function, which contributed to immune tolerance and facilitated viral persistence. Blocking IL-10 or administering antiviral therapy restored NK cell activation and IFN- $\gamma$ production. Impaired NK cell function induced by persistent HBV infection and chronic inflammation contributed to the progression of HCC. ${ }^{68}$

\section{B cells}

$B$ cells have been identified as potent regulators of $T$ cell immune responses in studies of autoimmunity, infection, and cancer. ${ }^{68-70} \mathrm{IL}-10$ is the primary mechanism by which $\mathrm{B}$ cells modulate other immune cells. These regulatory $B$ cells (Bregs) are pathogenic in parasitic infections, subverting $\mathrm{CD}^{+}{ }^{+}$cells toward a Th2 phenotype favorable to pathogen survival, and they can reduce Ag-specific $\mathrm{CD}^{+} \mathrm{T}$ cell responses through production of IL-10 in murine viral infection. ${ }^{71}$ In humans, it was recently demonstrated that analogous Breg subsets can suppress $\mathrm{CD} 4^{+} \mathrm{T}$ cell proliferation and IFN- $\gamma$ and TNF- $\alpha$ production by $\mathrm{CD}^{+}{ }^{+} \mathrm{T}$ cells as well as regulate TNF- $\alpha$ release by monocytes. ${ }^{72}$ The suppressive effects were mediated by IL-10 and were independent of TGF- $\beta$.

There is little data available regarding the role of Bregs in human viral infection. A recent report longitudinally studied serum IL-10 levels in patients with CHB undergoing spontaneous disease flares. There was a close temporal correlation between IL-10 levels and fluctuations in viral load or liver inflammation. Blockade of IL-10 in vitro rescued polyfunctional virus-specific $\mathrm{CD}^{+} \mathrm{T}$ cell responses. These data revealed that a novel $\mathrm{IL}-10$-producing subset of $\mathrm{B}$ cells were able to regulate $\mathrm{T}$ cell immunity in $\mathrm{CHB} .{ }^{73}$

\section{Monocytes}

Although circulating monocytes represent about $10 \%$ of leukocytes in human blood, relatively little is known on the effects of chronic viral infections on monocytes. Impaired monocyte functions have been reported in human immunodeficiency virus (HIV) infections, ${ }^{74,75}$ and TLR responsiveness of monocytes has been obtained from patients with chronic hepatitis $\mathrm{C}$ virus (HCV) infections. ${ }^{76,77}$ Monocytes can be divided into two distinct subpopulations based on the surface expression of CD14 and CD16. CD $14^{\text {high }} \mathrm{CD} 16^{-}$monocytes make up the majority (80-90\%) of blood monocytes and have been reported to produce relatively high IL-10 and low TNF levels, whereas the $\mathrm{CD} 14^{+} \mathrm{CD} 16^{+}$subpopulation produces higher levels of the pro-inflammatory cytokines TNF and IL-1ß. ${ }^{78,79}$

In chronic HBV, some studies reported modulation of the monocyte compartment as a result of the disease. Depending on the clinical phase of the chronic HBV infection, altered monocyte subset frequencies were reported. ${ }^{80,81}$ Moreover, peripheral blood mononuclear cells (PBMCs) from $\mathrm{HBeAg-}$ positive patients produced less TNF and IL- 6 upon stimulation with TLR2 agonists as compared to HBeAg-negative patients, ${ }^{82}$ which may be due to lower expression of TLR2 in HBeAg-positive patients. ${ }^{83}$ Furthermore, exposure of monocytes to HBsAg suppressed lipopolysaccharide (LPS)-induced TNF and IL- $1 \beta$ production in vivo and in vitro. ${ }^{84,85}$ There was a link between HBsAg and decreased cytokine production induced by the TLR2 ligand (Pam3csk4) in PBMCs from $\mathrm{CHB}$ patients in vivo. ${ }^{86}$ This finding demonstrated that $\mathrm{HBsAg}$ selectively inhibited Pam3csk4-stimulated IL-12 production. HBsAg inhibited the jun N-terminal kinase-mitogen activated protein kinase (JNK-MAPK) pathway, and it may be by this mechanism that HBV evades the immune system and maintains its persistence. ${ }^{87}$ 


\section{Kupffer cells}

Kupffer cells (KCs) are nonparenchymal cells that account for approximately $15 \%$ of the total liver cell population and constitute $80-90 \%$ of the tissue-resident macrophages in the whole body. Due to their intravascular (sinusoidal) localization, KCs have long been studied as scavenger cells that physiologically remove particulate material from the portal circulation. ${ }^{88}$ In recent years, KCs have been implicated in the pathogenesis of an assortment of inflammatory liver diseases, including viral hepatitis. ${ }^{89}$ Accordingly, the current dogma regarding the role of KCs in HBV pathogenesis considers these cells as important contributors to liver injury. ${ }^{90}$

The liver is continuously exposed to nonpathogenic antigens (from food) and to gut-derived LPS. LPS is a powerful stimulus for innate immunity through TLR ligation and activation of professional APCs. The elaboration of IL-10 by KCs is one mechanism by which to modulate the host response to proinflammatory cytokines (IL-12, IL-15, and IL-18) also secreted by $\mathrm{KCs} .{ }^{91} \mathrm{KCs}$ are intravascular macrophages that are continuously exposed to, and tolerant of, bacterial TLR ligands, which are delivered via the portal circulation. By mimicking a bacterial TLR2 ligand and effectively blocking the TLR3-mediated, double-stranded RNA (dsRNA)-induced antiviral response, $\mathrm{HCV}$ core protein might exploit this unique aspect of immunity in the liver. ${ }^{92}$ Like HCV, HBV is also a liver specific virus that produces a lot of viral proteins, DNAs, dsRNAs, and so on. They may interact with KCs through TLRs or other receptors and initiate liver damage or other immune cell responses.

\section{DCs}

Dendritic cells (DC) are considered to be professional antigen presenting cells that initiate primary immune responses, combining innate and adaptive immunity. DC plays an important role in activation of $\mathrm{CD} 8^{+} \mathrm{CTL}$ and $\mathrm{CD} 4^{+}$Th cells. Bioactive cytokines released by DC can stimulate NK cells, induce Th1 to produce cytokines and promote the proliferation of CTL. ${ }^{93}$ At least two DC subsets have been found in human and mouse peripheral blood, named precursor DC1 and DC2 (pDC1 and pDC2). pDC1, also called myeloid $D C(\mathrm{mDC})$ or antigen presenting cells type 1 , expresses CD11c and CD1a, and its expression is mainly correlated with antigen ingestion and activation of naïve T cells. pDC2 or IFN producing cells (IPCs) express CD123, CD4, MHC-II molecules, and BDCA-2 antigen. During different stages of infection in patients with hepatitis $B$, the frequency and quantity of DC declined significantly, with maturation disorder and function defects, resulting in inadequate effective immune response to clear virus. ${ }^{94,95}$

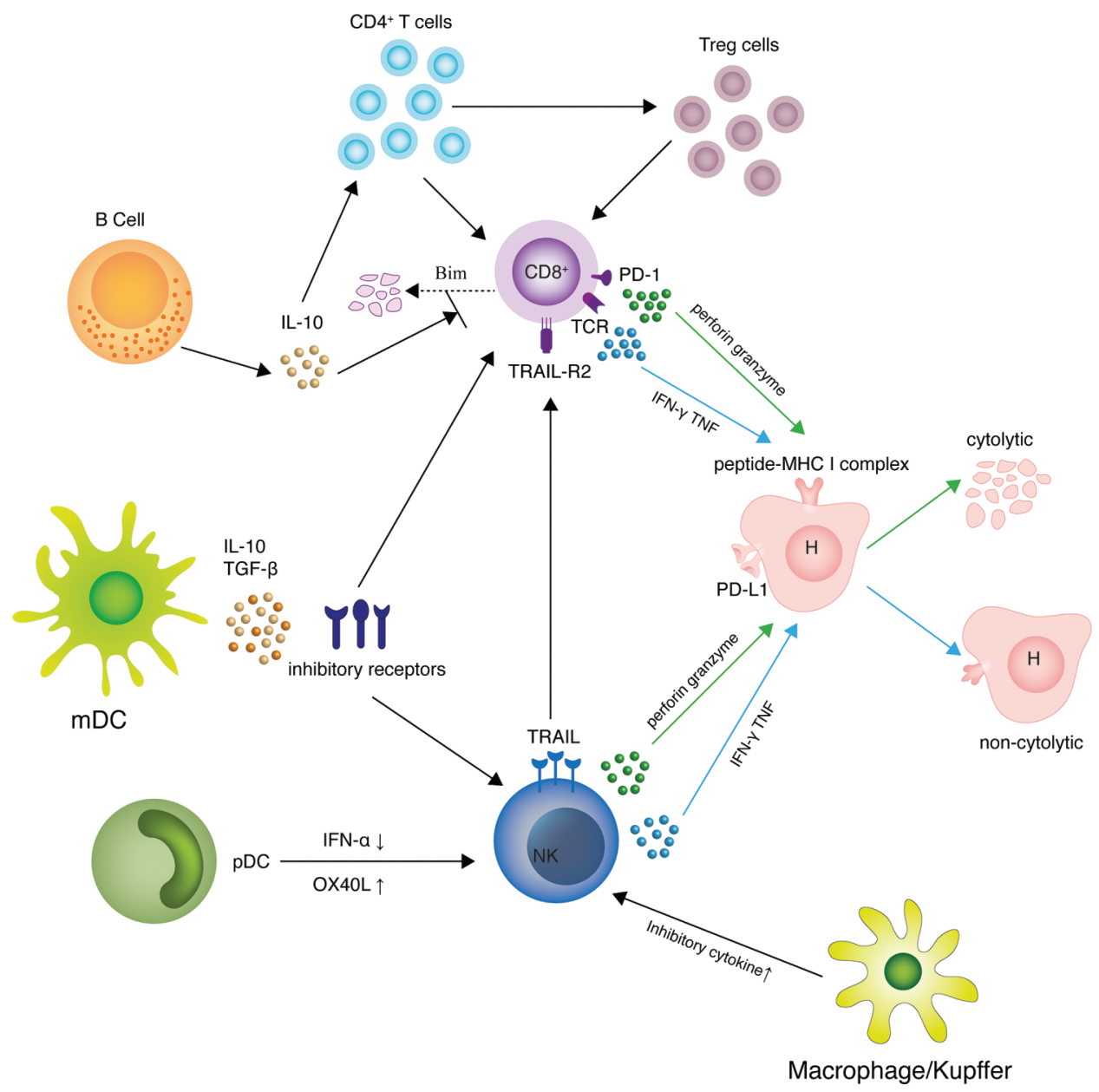

Fig. 1. Natural killer cells and hepatitis B virus (HBV)-specific CD8 ${ }^{+} \mathrm{T}$ cells are centrally involved in the $\mathrm{HBV}_{\mathrm{immune}}$ response. 
pDC2 is more sensitive than pDC1 when evaluating disease progress in patients with hepatitis $B$, with pDC2 declined in the early stage of infection and pDC1 declined later.

Broadly speaking, DCs are hematopoietically-derived cells that efficiently link the innate and the adaptive immune responses. Functionally, impaired DCs play important roles in suppressing host immune responses as well as facilitating viral persistence in chronic HBV infection. ${ }^{96}$ HBV DNA can be recognized by DCs through TLR9, and HBsAg can be internalized by DCs through the mannose receptor. ${ }^{97}$ DCs phagocytize hepatitis $B$ virus, process them into antigenic peptides and present them to $\mathrm{CD} 4^{+}$and $\mathrm{CD} 8^{+} \mathrm{T}^{\mathrm{c}}$ cells. ${ }^{98} \mathrm{DCs}$ activate antibody-dependent cytotoxicity (ADCC) cells and NK cells, which stimulate these cells to secrete immunosuppressive cytokines IL-10 and TGF- $\beta$, thereby assisting in the induction of Tregs with the participation of mDCs to destroy HBV-infected hepatocytes. ${ }^{99}$ DCs undergo a process called maturation in the presence of inflammatory signals, such as proinflammatory cytokines, microbial products, and other endogenous signals.

Circulating blood pDC numbers seem to be unaffected by $\mathrm{HBV}$, but functional deficits in pDCs from chronic HBV patients, including impaired IFN- $\alpha$ production, have been reported. ${ }^{100}$ Recently, it was shown that patient-derived HBsAg could bind to human pDC in vitro and impair TLR9induced IFN- $\alpha$ production by pDCs. ${ }^{101}$ Although circulating and intrahepatic pDCs from patients with chronic HBV infection showed a more activated phenotype, their ability to respond to TLR-9 stimulation was significantly impaired. Moreover, patient-derived mature pDCs were poor activators of NK cell cytotoxic function due to impaired IFN- $\alpha$ secretion and reduced OX40 ligand expression. HBV seems not only to directly inhibit pDC maturation in a TLR9-dependent manner but also to abrogate the supporting function of monocytes regarding IFN- $\alpha$ production by pDCs. ${ }^{102,103}$

Taken together, these findings suggest that chronic HBV infection could lead to decreased DC function and inhibition of Tcell activation. Therefore, the quantity and dynamic changes of DCs are closely related to immune status and reactivity of antiviral therapy. DC function may become a valid index for the assessment of disease progress and efficacy of antiviral therapy.

\section{Conclusions}

Recently, knowledge of the tolerogenic liver environment and the key cell populations in local hepatic immune regulation has rapidly grown. Despite these important insights, which are primarily based on studies performed in genetically modified mouse models, very little information is available about the specific role of these cell populations and the molecular mechanisms of hepatic immune surveillance in human viral infection, especially in chronic HBV infection.

Chronicity of HBV is the result of a complex interaction between the replicating virus and an inadequate immune response (Fig. 1). After infection, viral replication occurs in hepatocytes, and the secretion of infectious virions can take place for decades at high rates. Consequently, HBV DNA, as well as viral proteins like $\mathrm{HBeAg}$ and $\mathrm{HBsAg}$, can be easily detected in serum. Immune cells in the liver respond to these stimuli differently and secrete special cytokines at different disease stages. Immune cells in the liver construct a complex net and cytokine map that is not only influenced by themselves but also other cell types. The cross-talk between immune cells and the mechanisms controlling virus replication have become more popular recently. A better understanding of the mechanisms leading to viral persistence may result in new therapeutic treatment strategies that aim to remedy the immune cell defects described, thereby augmenting functional responses and decreasing antigenunspecific liver damage.

\section{Acknowledgments}

This paper was supported in part by a grant from Jilin Provincial Natural Science Foundation of China (No. 20140520014JH) and The $4^{\text {th }}$ young scientist fund of Jilin University (No. 2013068).

\section{Conflict of interest}

None.

\section{Author contributions}

Writing the manuscript $(\mathrm{HJL})$, collecting the data and references (NCZ, HXS, YY, AC), drawing the pictures (TYL), critically reviewing the manuscript (ZKT).

\section{References}

[1] Honer Zu Siederdissen C, Cornberg M. The role of HBsAg levels in the current management of chronic HBV infection. Ann Gastroenterol 2014; 27:105-112.

[2] Ott J], Stevens GA, Groeger J, Wiersma ST. Global epidemiology of hepatitis B virus infection: new estimates of age-specific $\mathrm{HBsAg}$ seroprevalence and endemicity. Vaccine 2012;30:2212-2219. doi: 10.1016/j.vaccine. 2011.12.116.

[3] Peppa D, Gill US, Reynolds G, Easom NJ, Pallett LJ, Schurich A, et al. Upregulation of a death receptor renders antiviral $T$ cells susceptible to NK cellmediated deletion. J Exp Med 2013;210:99-114. doi: 10.1084/jem. 20121172.

[4] Boonstra A, Woltman AM, Janssen HL. Immunology of hepatitis B and hepatitis C virus infections. Best Pract Res Clin Gastroenterol 2008;22: 1049-1061. doi: 10.1016/j.bpg.2008.11.015

[5] Ganem D, Prince AM. Hepatitis B virus infection-natural history and clinical consequences. N Engl J Med 2004;350:1118-1129. doi: 10. 1056/NEJMra031087.

[6] Rehermann B, Nascimbeni M. Immunology of hepatitis B virus and hepatitis C virus infection. Nat Rev Immunol 2005;5:215-229. doi: 10.1038/nri1573.

[7] Tu Z, Bozorgzadeh A, Crispe IN, Orloff MS. The activation state of human intrahepatic lymphocytes. Clin Exp Immunol 2007;149:186-193. doi: 10. 1111/j.1365-2249.2007.03415.x.

[8] Schwartz, RH. T cell anergy. Annu Rev Immunol 2003;21:305-334. doi: 10. 1146/annurev.immunol.21.120601.141110.

[9] Chen M, Sällberg M, Hughes J, Jones J, Guidotti LG, Chisari FV, et al. Immune tolerance split between hepatitis $B$ virus precore and core proteins. J Virol 2005;79:3016-3027. doi: 10.1128/JVI.79.5.3016-3027.2005.

[10] Ganem D, Prince AM. Hepatitis B virus infection-natural history and clinical consequences. N Engl J Med 2004;350:1118-1129. doi: 10. 1056/NEJMra031087.

[11] Rehermann B, Nascimbeni M. Immunology of hepatitis B virus and hepatitis C virus infection. Nat Rev Immunol 2005;5:215-229. doi: 10. $1038 /$ nri1573.

[12] Boonstra A, Woltman AM, Janssen HL. Immunology of hepatitis B and hepatitis C virus infections. Best Pract Res Clin Gastroenterol 2008;22: 1049-1061. doi: 10.1016/j.bpg.2008.11.015.

[13] China Tuberculosis Control Collaboration. The effect of tuberculosis control in China. Lancet 2004;364:417-422. doi: 10.1016/S0140-6736(04) 16764-0.

[14] Custer B, Sullivan SD, Hazlet TK, Iloeje U, Veenstra DL, Kowdley KV. Global epidemiology of hepatitis B virus. J Clin Gastroenterol 2004;38:S158S168. doi: 10.1097/00004836-200411003-00008.

[15] Parkin DM, Bray F, Ferlay J, Pisani P. Global cancer statistics, 2002. CA Cancer J Clin 2005;55:74-108. doi: 10.3322/canjclin.55.2.74. 
[16] Tanaka M, Katayama F, Kato H, Tanaka H, Wang J, Qiao $\mathrm{YL}$, et al. Hepatitis $\mathrm{B}$ and $C$ Virus Infection and Hepatocellular Carcinoma in China: A Review of Epidemiology and Control Measures. J Epidemiol 2011;21:401-416. doi: 10.2188/jea.JE20100190.

[17] Zhang N, Bevan MJ. CD8(+) T cells: foot soldiers of the immune system. Immunity $2011 ; 35: 161-168$. doi: 10.1016/j.immuni.2011.07.010.

[18] Youngblood B, Hale JS, Ahmed R. T-cell memory differentiation: insights from transcriptional signatures and epigenetics. Immunology 2013;139: 277-284. doi: 10.1111/imm.12074.

[19] Appay V, Van Lier RA, Sallusto F, Roederer M. Phenotype and function of human T lymphocyte subsets: consensus and issues. Cytometry A 2008; 73:975-983. doi: 10.1002/cyto.a.20643.

[20] Maini MK, Boni C, Lee CK, Larrubia JR, Reignat S, Ogg GS, et al. The role of virus-specific $\mathrm{CD} 8(+)$ cells in liver damage and viral control during persistent hepatitis B virus infection. J Exp Med 2000;191:1269-1280. doi: 10. 1084/jem.191.8.1269.

[21] Ferrari C, Penna A, Bertoletti A, Valli A, Antoni AD, Giuberti T, et al. Cellular immune response to hepatitis $B$ virus-encoded antigens in acute and chronic hepatitis B virus infection. J Immunol 1990;145:3442-3449.

[22] Bertoletti A, Costanzo A, Chisari FV, Levrero M, Artini M, Sette A, et al. Cytotoxic $T$ lymphocyte response to a wild type hepatitis $B$ virus epitope in patients chronically infected by variant viruses carrying substitutions within the epitope. J Exp Med 1994;180:933-943. doi: 10.1084/jem.180.3.933

[23] Webster G], Reignat S, Brown D, Ogg GS, Jones L, Seneviratne SL, et al. Longitudinal analysis of CD8+ T cells specific for structural and nonstructural hepatitis B virus proteins in patients with chronic hepatitis B: implications for immunotherapy. J Virol 2004;78:5707-5719. doi: 10.1128/JVI.78. 11.5707-5719.2004.

[24] Lopes AR, Kellam P, Das A, Dunn C, Kwan A, Turner J, et al. Bim-mediated deletion of antigen-specific CD8 T cells in patients unable to control HBV infection. J Clin Invest 2008;118:1835-1845. doi: 10.1172/JCI33402.

[25] Appay V, Van Lier RA, Sallusto F, Roederer M. Phenotype and function of human T lymphocyte subsets: consensus and issues. Cytometry A 2008; 73:975-983. doi: 10.1002/cyto.a.20643.

[26] Boni C, Fisicaro P, Valdatta C, Amadei B, Di Vincenzo P, Giuberti T, et al. Characterization of hepatitis $B$ virus (HBV)-specific T-cell dysfunction in chronic HBV infection. J Virol 2007;81:4215-4225. doi: 10.1128/JVI.02844-06.

[27] Fisicaro P, Valdatta C, Massari M, Loggi E, Biasini E, Sacchelli L, et al. Antiviral intrahepatic T-cell responses can be restored by blocking programmed death-1 pathway in chronic hepatitis B. Gastroenterology 2010;138:682693, e1-e4. doi: 10.1053/j.gastro.2009.09.052.

[28] Schurich A, Khanna P, Lopes AR, Han KJ, Peppa D, Micco L, et al. Role of the coinhibitory receptor cytotoxic $T$ lymphocyte antigen-4 on apoptosisprone CD8 T cells in persistent hepatitis B virus infection. Hepatology 2011;53: 1494-1503. doi: 10.1002/hep.24249.

[29] Nebbia G, Peppa D, Schurich A, Khanna P, Singh HD, Cheng Y, et al. Upregulation of the Tim-3/galectin-9 pathway of $T$ cell exhaustion in chronic hepatitis B virus infection. PLoS One 2012;7:e47648. doi: 10. 1371/journal.pone.0047648.

[30] Wu W, Shi Y, Li S, Zhang Y, Liu Y, Wu Y, et al. Blockade of Tim-3 signaling restores the virus-specific $\mathrm{CD} 8(+)$ T-cell response in patients with chronic hepatitis B. Eur J Immunol 2012;42:1180-1191. doi: 10.1002/eji. 201141852.

[31] Raziorrouh B, Schraut W, Gerlach T, Nowack D, Gruner NH, Ulsenheimer A et al. The immunoregulatory role of CD244 in chronic hepatitis B infection and its inhibitory potential on virus-specific CD8+ T-cell function. Hepatology 2010;52:1934-1947. doi: 10.1002/hep.23936.

[32] Muhlbauer M, Fleck M, Schutz C, Weiss T, Froh M, Blank $C$, et al. PD-L1 is induced in hepatocytes by viral infection and by interferon-alpha and -gamma and mediates T cell apoptosis. J Hepatol 2006;45:520-528. doi: 10.1016/j.jhep.2006.05.007.

[33] Knolle PA, Thimme R. Hepatic immune regulation and its involvement in viral hepatitis infection. Gastroenterology 2014;146:1193-1207. doi: 10. 1053/j.gastro.2013.12.036.

[34] Maier H, Isogawa M, Freeman GJ, Chisari FV. PD-1:PD-L1 interactions contribute to the functional suppression of virus-specific CD8+ T lymphocytes in the liver. J Immunol 2007; 178:2714-2720. doi: 10.4049/jimmunol.178. 5.2714 .

[35] Yang PL, Althage A, Chung J, Maier $\mathrm{H}$, Wieland $\mathrm{S}$, Isogawa $\mathrm{M}$, et al. Immune effectors required for hepatitis B virus clearance. Proc Natl Acad Sci USA 2010;107:798-802. doi: 10.1073/pnas.0913498107.

[36] Stoop JN, van der Molen RG, Baan CC, van der Laan LJ, Kuipers EJ, Kusters JG, et al. Regulatory $T$ cells contribute to the impaired immune response in patients with chronic hepatitis B virus infection. Hepatology 2005;41: 771-778. doi: 10.1002/hep.20649.

[37] Xu D, Fu J, Jin L, Zhang H, Zhou C, Zou Z, et al. Circulating and liver resident $\mathrm{CD} 4+\mathrm{CD} 25+$ regulatory $T$ cells actively influence the antiviral immune response and disease progression in patients with hepatitis B. J Immunol 2006;177:739-747. doi: 10.4049/jimmunol.177.1.739.
[38] Yang G, Liu A, Xie O, Guo TB, Wan B, Zhou B, et al. Association of CD4+CD25+Foxp3+ regulatory $T$ cells with chronic activity and viral clearance in patients with hepatitis B. Int Immunol 2007;19:133-140. doi: 10. 1093/intimm/dxl130.

[39] Dunn C, Peppa D, Khanna P, Nebbia G, Jones M, Brendish N, et al. Temporal analysis of early immune responses in patients with acute hepatitis $B$ virus infection. Gastroenterology 2009;137:1289-1300. doi: 10.1053/j.gastro. 2009.06.054

[40] Peppa D, Micco L, Javaid A, Kennedy PT, Schurich A, Dunn C, et al. Blockade of immunosuppressive cytokines restores NK cell antiviral function in chronic hepatitis B virus infection. PLoS Pathog 2010;6:e1001227. doi: 10.1371/journal.ppat.1001227.

[41] Das A, Ellis G, Pallant C, Lopes AR, Khanna P, Peppa D, et al. IL-10-producing regulatory $B$ cells in the pathogenesis of chronic hepatitis $B$ virus infection. J Immunol 2012;189:3925-3935. doi: 10.4049/jimmunol.1103139.

[42] Kurktschiev PD, Raziorrouh B, Schraut W, Backmund M, Wächtler M, Wendtner $\mathrm{CM}$, et al. Dysfunctional CD8(+) T cells in hepatitis B and C are characterized by a lack of antigen-specific T-bet induction. J Exp Med 2014;211: 2047-2059. doi: 10.1084/jem.20131333.

[43] Kao C, Oestreich KJ, Paley MA, Crawford A, Angelosanto JM, Ali MA, et al. Transcription factor T-bet represses expression of the inhibitory receptor $\mathrm{PD}-1$ and sustains virus-specific $\mathrm{CD} 8^{+} \mathrm{T}$ cell responses during chronic infection. Nat Immunol 2011;12:663-671. doi: 10.1038/ni.2046.

[44] Ye B, Liu X, Li X, Kong H, Tian L, Chen Y. T-cell exhaustion in chronic hepatitis $B$ infection: current knowledge and clinical significance. Cell Death Dis 2015;6:e1694. doi: 10.1038/cddis.2015.42.

[45] Ghoreishi M, Dutz JP. Tolerance induction by transcutaneous immunization through ultraviolet-irradiated skin is transferable through CD4+CD25+ T regulatory cells and is dependent on host-derived IL-10. J Immunol 2006; 176:2635-2644. doi: 10.4049/jimmunol.176.4.2635.

[46] Fucs $R$, Jesus JT, Souza Junior PH, Franco L, Verícimo M, Bellio M, et al. Frequency of natural regulatory $C D 4+C D 25+T$ lymphocytes determines the outcome of tolerance across fully mismatched MHC barrier through linked recognition of self and allogeneic stimuli. J Immunol 2006;176: 2324-2329. doi: 10.4049/jimmunol.176.4.2324.

[47] Asiedu CK, Goodwin KJ, Balgansuren G, Jenkins SM, Le Bas-Bernardet S, Jargal $U$, et al. Elevated $T$ regulatory cells in long-term stable transplant tolerance in rhesus macaques induced by anti-CD3 immunotoxin and deoxyspergualin. J Immunol 2005;175:8060-8068. doi: 10.4049/jimmunol. 175.12 .8060

[48] Viglietta $\mathrm{V}$, Baecher-Allan $\mathrm{C}$, Weiner $\mathrm{HL}$, Hafler DA. Loss of functional suppression by $C D 4+C D 25+$ regulatory T cells in patients with multiple sclerosis. J Exp Med 2004;199:971-979. doi: 10.1084/jem.20031579.

[49] Cao D, Malmström V, Baecher-Allan C, Hafler D, Klareskog L, Trollmo C. Isolation and functional characterization of regulatory CD25brightCD4+T cells from the target organ of patients with rheumatoid arthritis. Eur J Immunol 2003;33:215-223. doi: 10.1002/immu.200390024.

[50] Smyth MJ, Teng MW, Swann J, Kyparissoudis K, Godfrey DI, Hayakawa Y. CD4+CD25+T regulatory cells suppress NK cell-mediated immunotherapy of cancer. J Immunol 2006;176:1582-1587. doi: 10.4049/jimmunol.176.3. 1582.

[51] Rouse BT, Suvas S. Regulatory cells and infectious agents: detentes cordiale and contraire. J Immunol 2004;173:2211-2215. doi: 10.4049/jimmunol. 173.4.2211.

[52] Stoop JN, van der Molen RG, Baan CC, van der Laan LJ, Kuipers EJ, Kusters JG, et al. Regulatory T cells contribute to the impaired immune response in patients with chronic hepatitis B virus infection. Hepatology 2005;41: 771-778, doi: 10.1002/hep.20649.

[53] Xu D, Fu J, Jin L, Zhang H, Zhou C, Zou Z, et al. Circulating and liver resident $\mathrm{CD} 4+\mathrm{CD} 25+$ regulatory $\mathrm{T}$ cells actively influence the antiviral immune response and disease progression in patients with hepatitis $B$. J Immunol 2006;177:739-747. doi: 10.4049/jimmunol.177.1.739.

[54] Vandenbark AA, Chou YK, Whitham R, Mass M, Buenafe A, Liefeld D, et al. Treatment of multiple sclerosis with T-cell receptor peptides: results of a double-blind pilot trial. Nat Med 1996;2:1109-1115. doi: 10.1038/nm10961109.

[55] Kondo Y, Ueno Y, Ninomiya M, Tamai K, Tanaka Y, Inoue J, et al. Sequential immunological analysis of $\mathrm{HBV} / \mathrm{HCV}$ co-infected patients during PegIFN/RBV therapy. J Gastroenterol 2012;47:1323-1335. doi: 10. 1007/s00535-012-0596-X.

[56] Kondo $Y$, Shimosegawa T. Significant roles of regulatory T cells and myeloid derived suppressor cells in hepatitis $B$ virus persistent infection and hepatitis B virus-related HCCs. Int J Mol Sci 2015;16:3307-3322. doi: 10. 3390/ijms16023307.

[57] Li F, Wei H, Gao Y, Xu L, Yin W, Sun R, et al. Blocking the Natural Killer (NK) Cell Inhibitory Receptor NKG2A Increases Activity of Human NK Cells and Clears HBV Infection in Mice. Gastroenterology 2013;144:392-401. doi: 10.1053/j.gastro.2012.10.039. 
[58] Doherty DG, O'Farrelly C. Innate and adaptive lymphoid cells in the human liver. Immunol Rev 2000;174:5-20. doi: 10.1034/j.1600-0528.2002. 017416.x.

[59] Gregoire C, Chasson L, Luci C, Tomasello E, Geissmann F, Vivier E, et al. The trafficking of natural killer cells. Immunol Rev 2007;220:169-182. doi: 10 . 1111/j.1600-065X.2007.00563.x.

[60] Mackay IR. Hepatoimmunology: a perspective. Immunol Cell Biol 2002;80: 36-44. doi: 10.1046/j.1440-1711.2002.01063.x.

[61] Oliviero B, Varchetta S, Paudice E, Michelone G, Zaramella M, Mavilio D et al. Natural killer cell functional dichotomy in chronic hepatitis B and chronic hepatitis C virus infections. Gastroenterology 2009;137:11511160.e1-e7. doi: 10.1053/j.gastro.2009.05.047.

[62] Zhang Z, Zhang S, Zou Z, Shi J, Zhao J, Fan R, et al. Hypercytolytic activity of hepatic natural killer cells correlates with liver injury in chronic hepatitis $B$ patients. Hepatology 2011;53:73-85. doi: 10.1002/hep.23977.

[63] Tjwa ET, Van Oord GW, Hegmans JP, Janssen HL, Woltman AM. Viral load reduction improves activation and function of natural killer cells in patients with chronic hepatitis B. J Hepatol 2011;54:209-218. doi: 10.1016/j.jhep. 2010.07.009.

[64] Nattermann J, Feldmann G, Ahlenstiel G, Langhans B, Sauerbruch T, Spengler U. Surface expression and cytolytic function of natural killer cell receptors is altered in chronic hepatitis C. Gut 2006;55:869-877. doi: 10. $1136 /$ gut.2005.076463.

[65] Ju Y, Hou N, Meng J, Wang $X$, Zhang $X$, Zhao D, et al. T cell immunoglobulinand mucin-domain-containing molecule-3 (Tim-3) mediates natural killer cell suppression in chronic hepatitis B. J Hepatol 2010;52:322-329. doi: 10.1016/j.jhep.2009.12.005

[66] Tang KF, Chen M, Xie J, Song GB, Shi YS, Liu Q, et al. Inhibition of hepatitis B virus replication by small interference RNA induces expression of MICA in HepG2.2.15 cells. Med Microbiol Immunol 2009;198:27-32. doi: 10. 1007/s00430-008-0101-6.

[67] Peppa D, Micco L, Javaid A, Kennedy PT, Schurich A, Dunn C, et al. Blockade of immunosuppressive cytokines restores NK cell antiviral function in chronic hepatitis B virus infection. PLoS Pathog 2010;6:e1001227. doi: 10.1371 /journal.ppat. 1001227.

[68] Sun C, Sun H, Zhang C, Tian Z. NK cell receptor imbalance and NK cell dysfunction in HBV infection and hepatocellular carcinoma. Cell Mol Immunol 2015;12:292-302. doi: 10.1038/cmi.2014.91.

[69] Yanaba K, Bouaziz JD, Haas KM, Poe JC, Fujimoto M, Tedder TF. A regulatory B cell subset with a unique $\mathrm{CD} 1 \mathrm{~d}^{\mathrm{hi}} \mathrm{CD} 5^{+}$phenotype controls T cell-dependent inflammatory responses. Immunity 2008;28:639-650. doi: $10.1016 / \mathrm{j}$. immuni.2008.03.017.

[70] Yanaba K, Yoshizaki A, Asano Y, Kadono T, Tedder TF, Sato S. IL-10-producing regulatory B10 cells inhibit intestinal injury in a mouse model. Am J Pathol 2011;178:735-743. doi: 10.1016/j.ajpath.2010.10.022.

[71] Ronet C, Hauyon-La Torre Y, Revaz-Breton M, Mastelic B, Tacchini-Cottier F, Louis J, et al. Regulatory B cells shape the development of Th2 immune responses in BALB/c mice infected with Leishmania major through IL-10 production. J Immunol 2010;184:886-894. doi: 10.4049/jimmunol.0901114.

[72] Iwata Y, Matsushita T, Horikawa M, Dilillo DJ, Yanaba K, Venturi GM, et al. Characterization of a rare IL-10-competent B-cell subset in humans that parallels mouse regulatory B10 cells. Blood 2011;117:530-541. doi: 10. 1182/blood-2010-07-294249.

[73] Das A, Ellis G, Pallant C, Lopes AR, Khanna P, Peppa D, et al. IL-10-Producing Regulatory B Cells in the Pathogenesis of Chronic Hepatitis B Virus Infection. J Immunol 2012;189:3925-3935. doi: 10.4049/jimmunol.1103139.

[74] Dunn C, Peppa D, Khanna P, Nebbia G, Jones M, Brendish N, et al. Temporal analysis of early immune responses in patients with acute hepatitis $B$ virus infection. Gastroenterology 2009;137:1289-1300. doi: 10.1053/j.gastro. 2009.06.054.

[75] Nockher WA, Bergmann L, Scherberich JE. Increased soluble CD14 serum levels and altered CD14 expression of peripheral blood monocytes in HIVinfected patients. Clin Exp Immunol 1994;98:369-374. doi: 10.1111/j. 1365-2249.1994.tb05499.x.

[76] Nockher WA, Scherberich JE. Expanded CD14+ CD16+ monocyte subpopulation in patients with acute and chronic infections undergoing hemodialysis. Infect Immun 1998;66:2782-2790.

[77] Liu BS, Groothuismink ZM, Janssen HL, Boonstra A. Role for IL-10 in inducing functional impairment of monocytes upon TLR4 ligation in patients with chronic HCV infections. J Leukoc Biol 2011;89:981-988. doi: 10.1189/jlb. 1210680.

[78] Peng C, Liu BS, de Knegt RJ, Janssen HL, Boonstra A. The response to TLR ligation of human CD16(+)CD14(-) monocytes is weakly modulated as a consequence of persistent infection with the hepatitis $C$ virus. Mol Immunol 2011;48:1505-1511. doi: 10.1016/j.molimm.2011.04.008.

[79] Auffray C, Sieweke MH, Geissmann F. Blood monocytes: development, heterogeneity, and relationship with dendritic cells. Annu Rev Immunol 2009; 27:669-692. doi: 10.1146/annurev.immunol.021908.132557.

[80] Cros J, Cagnard N, Woollard K, Patey N, Zhang SY, Senechal B, et al. Human CD14dim monocytes patrol and sense nucleic acids and viruses via TLR7 and TLR8 receptors. Immunity 2010;33:375-386. doi: 10.1016/j.immuni. 2010.08.012.

[81] Anthony DD, Umbleja T, Aberg JA, Kang M, Medvik K, Lederman MM, et al. Lower peripheral blood $\mathrm{CD} 14+$ monocyte frequency and higher $\mathrm{CD} 34^{+}$progenitor cell frequency are associated with HBV vaccine induced response in HIV infected individuals. Vaccine 2011;29:3558-3563. doi: 10.1016/j. vaccine.2011.02.092

[82] Zhang JY, Zou ZS, Huang A, Zhang Z, Fu JL, Xu XS, et al. Hyper-activated proinflammatory CD16 monocytes correlate with the severity of liver injury and fibrosis in patients with chronic hepatitis B. PLoS One $2011 ; 6: \mathrm{e} 17484$. doi: $10.1371 /$ journal.pone.0017484.

[83] Visvanathan K, Skinner NA, Thompson AJV, Riordan SM, Sozzi V, Edwards R, et al. Regulation of Toll-like receptor-2 expression in chronic hepatitis $B$ by the precore protein. Hepatology 2007;45:102-110. doi: 10.1002/hep.21482.

[84] Riordan SM, Skinner N, Kurtovic ], Locarnini S, Visvanathan K. Reduced Expression of Toll-Like Receptor 2 on Peripheral Monocytes in Patients with Chronic Hepatitis B. Clin Vaccine Immunol 2006;13:972-974. doi: 10.1128/CVI.00396-05

[85] Boltjes A, Groothuismink ZM, van Oord GW, Janssen HL, Woltman AM, Boonstra A. Monocytes from Chronic HBV Patients React In vitro to HBsAg and TLR by Producing Cytokines Irrespective of Stage of Disease. PLoS One 2014;9:e97006. doi: 10.1371/journal.pone.0097006.

[86] Chen Z, Cheng Y, Xu Y, Liao J, Zhang X, Hu Y, et al. Expression profiles and function of Tolllike receptors 2 and 4 in peripheral blood mononuclear cells of chronic hepatitis B patients. Clin Immunol 2008;128:400-408. doi: 10. 1016/j.clim.2008.04.006.

[87] Wang S, Chen Z, Hu C, Qian F, Cheng Y, Wu M, et al. Hepatitis B Virus Surface Antigen Selectively-Inhibits TLR2 Ligand Induced IL-12 Production in Monocytes/Macrophages by Interfering with JNK Activation. J Immunol 2013;190:5142-5151. doi: 10.4049/jimmunol.1201625.

[88] Vollmar B, Menger MD. The hepatic microcirculation: mechanistic contributions and therapeutic targets in liver injury and repair. Physiol Rev 2009;89: 1269-1339. doi: 10.1152/physrev.00027.2008.

[89] Heydtmann M. Macrophages in hepatitis $B$ and hepatitis $C$ virus infections. J Virol 2009;83:2796-2802. doi: 10.1128/JVI.00996-08.

[90] Wu Z, Han M, Chen T, Yan W, Ning Q. Acute liver failure: mechanisms of immune-mediated liver injury. Liver Int 2010;30:782-794. doi: 10.1111/j. 1478-3231.2010.02262.x.

[91] Tu Z, Pierce RH, Kurtis J, Kuroki Y, Crispe IN, Orloff MS. Hepatitis C Virus Core Protein Subverts the Anti-Viral Activities of Human Kupffer Cells. Gastroenterology 2010;138:305-314. doi: 10.1053/j.gastro.2009.09.009.

[92] Tu Z, Bozorgzadeh A, Pierce RH, Kurtis ], Crispe IN, Orloff MS. TLR-dependent cross talk between human Kupffer cells and NK cells. J Exp Med 2008;205: 233-244. doi: 10.1084/jem.20072195.

[93] Li X, Wang Y, Chen Y. Cellular immune response in patients with chronic hepatitis B virus infection. Microb Pathog 2014;74:59-62. doi: 10.1016/j. micpath.2014.07.010.

[94] Li Y, Wang J], Gao S, Liu Q, Bai J, Zhao XQ, et al. Decreased peripheral natural killer cells activity in the immune activated stage of chronic hepatitis B. PLoS One 2014;9:e86927. doi: 10.1371/journal.pone.0086927.

[95] Ma Y], He M, Han JA, Yang L, Ji XY. A clinical study of HBsAg-activated dendritic cells and cytokine-induced killer cells during the treatment for chronic hepatitis B. Scand J Immunol 2013;78:387-393. doi: 10. $1111 /$ sji.12097.

[96] Sun HH, Zhou DF, Zhou JY. The role of DCs in the immunopathogenesis of chronic HBV infection and the methods of inducing DCs maturation. J Med Virol 2016;88:13-20. doi: 10.1002/jmv.24306.

[97] Cui GY, Diao HY. Recognition of HBV antigens and HBV DNA by dendritic cells. Hepatobiliary Pancreat Dis Int 2010;9:584-592.

[98] Ma Y], He M, Han JA, Yang L, Ji XY. A clinical study of HBsAg-activated dendritic cells and cytokine-induced killer cells during the treatment for chronic hepatitis B. Scand J Immunol 2013;78:387-393. doi: 10.1111/ sji.12097.

[99] Zhang Z, Zhang JY, Wang LF, Wang FS. Immunopathogenesis and prognostic immune markers of chronic hepatitis B virus infection. J Gastroenterol Hepatol 2012;27:223-230. doi: 10.1111/j.1440-1746.2011.06940.x.

[100] Kawai T, Akira S. Innate immune recognition of viral infection. Nat Immunol 2006; 7:131-137. doi: 10.1038/ni1303.

[101] Della Chiesa M, Sivori S, Castriconi R, Marcenaro E, Moretta A. Pathogeninduced private conversations between natural killer and dendritic cells. Trends Microbiol 2005;13:128-136. doi: 10.1016/j.tim.2005.01.006.

[102] Della Chiesa M, Romagnani C, Thiel A, Moretta L, Moretta A. Multidirectional interactions are bridging human NK cells with plasmacytoid and monocytederived dendritic cells during innate immune responses. Blood 2006;108: 3851-3858. doi: 10.1182/blood-2006-02-004028.

[103] Xu Y, Hu Y, Shi B, Zhang X, Wang J, Zhang Z, et al. HBsAg inhibits TLR9mediated activation and IFN-alpha production in plasmacytoid dendritic cells. Mol Immunol 2009;46:2640-2646. doi: 10.1016/j.molimm.2009. 04.031 . 